\section{Thatcher applauds genes}

Britain's Prime Minister, Mrs Margaret Thatcher, was told last week that the public stood to gain an annual return of 157 per cent on its investment in basic research into the applications of recombinant DNA techniques through cost reductions in pharmaceutical and other commercial products. In comparison, the heavy investment in research and development, as well as production facilities, meant that companies might on average expect a more modest return of about 15 per cent.

Mrs Thatcher was given these figures by $\mathrm{Dr}$ Leslie Glick, president of the Rockville-based company Genex Corporation, when she visited the company's laboratories during her stay in Washington. Dr Glick said that the company had calculated that in 20 years time, $\$ 40,000$ million out of $\$ 125,000$ million in worldwide sales of a variety of products would be obtained by using genetically engineered microorganisms. Out of the total, $\$ 140,000$ million would be obtained from microorganisms making products that already exist, and the remaining $\$ 26,000$ from products which are not now economical to make.

These figures would translate into earnings of $\$ 3,500$ million for corporations after 20 years, half coming from petrochemicals being made biologically. Total private investment in plant, equipment and research and development would total $\$ 24,000$ million; in contrast, public support for basic research was likely to be at the most $\$ 3,000$ million, whereas the public would benefit by $\$ 2,400$ million in savings and $\$ 2,300$ million in taxes on products sold.

Mrs Thatcher said that she "totally agreed" with Dr Glick's reservations about attempting to promote genetic engineering technology through government investment rather than private entrepreneurship. Individual investors were willing to risk something if they stood to gain a great deal, she said, and it was also exciting - "better than betting on horses".

\section{Darwin in California}

\section{No verdict}

\section{Washington}

Biology teachers in the United States are breathing a little more easily this week. Last Friday, a California judge ruled that the teaching of evolution in schools does not necessarily undermine the religious beliefs of those who accept the biblical description of human origins. The claim has been made by Mr Kelly Segraves, director of the Creation Science Research Center in San Diego, in a suit brought against the state's Board of Education on behalf of his son. But, after broad philosophical questions about conflict between the Darwinian and "creationist" interpretations of biology had been reduced to the narrower question of whether evolution is being taught too dogmatically in Californian schools, the judge ruled that he found little wrong with the state's present practices.

The case had excited wide interest and had been widely talked about as a successor to the Scopes "monkey trial" in Tennessee in 1925. Last week, the creationists swept in like lions, charging that the teaching of Darwinian evolution in schools was an offence to their religious beliefs, and thus a direct infringement of the First Amendment, which guarantees freedom of religion, but they left relatively tamed, arguing merely for changes in the guidelines which the state provides for public school biology teachers on how evolution should be taught. Their demands that alternative theories about human origins should be discussed in biology classes were dropped.

The turning point came on the second day of the trial, after the plaintiffs' attorney had claimed that there was a direct conflict between his clients' beliefs and the state's approach to teaching evolution, exemplified by the current guidelines, which state that evolution "has been going on for so long that it has produced all the groups and kinds of plants and animals now living" as evidence that his clients' religious rights were being infringed.

The attorney, Mr Robert Turner, then surprised the court by withdrawing the original complaint that the state was trying to establish the teaching of a secular religion through school biology teaching. Judge Irving $\mathrm{H}$. Perluss accordingly ruled out debate on the scientific beliefs of $\mathrm{Mr}$ Segraves and therefore any attempt to demonstrate the relative merits of creation theories and Darwinism. As a consequence, the defendants were not able, as they had planned, to call the twenty scientists recruited as witnesses for Darwinism by the National Association of Biology Teachers. They included Nobel Laureate Arthur Kornberg and astronomer Carl Sagan.

Another issue ruled out by the judge concerned school teaching practices. On the second day, the plaintiff's son, 13-yearold Kasy Segraves, said he had been taught that man evolved from the apes "as fact". The defendants sought to call his teacher as a witness, both to repeat a denial she had made in the press and to point out that the discussion had taken place in a social science, not a biology class. Judge Perluss refused to allow this line of argument, invoking a state law which bans evidence that would prejudice a case to a greater degree than the value of the evidence.

On the final day of the trial, a member of the state's Board of Education, Mrs Marian Drinker, testified that for the past eight years - and following earlier criticism of approved school textbooks by fundamentalist religious groups - the state had adopted a policy that Darwinian evolution should be taught as theory and not dogma. The board had at the time issued a statement requiring that in school texts "dogmatism should be changed to conditional statements where speculation is offered for origins", and that they "should emphasize 'how' and not the ultimate cause for origins". In his judgement, the judge directed that the Department of Education should recirculate a memorandum containing this policy statement to all schools in California, to textbook publishers and to anybody else who had received the guidelines in the past or would in the future.

Even this was interpreted as a partial victory by the creationists, who argued that it represented "the first move in a chess game", and vowed to continue their fight against the teaching of evolution in schools. The state authorities and their scientific advisers, however, said that the verdict was a complete vindication of the way that evolutionary theory is at present taught in biology classes, pointing out that the judge in his summing up had stressed the importance of not mixing religion and science.

David Dickson

\section{European space agency \\ Sixes and sevens}

The plans of Eric Quistgaard, the new director-general of the European Space Agency (ESA), have thrown the 11 member states into hot dispute over the agency's future. Three months after the plans were announced, the delegates to the council are no nearer agreeing a draft that would lay down the agency's structure and aims for the next 10 years. The fear that ESA may collapse if member states cannot reconcile their individual ambitions may be realized if agreement is not reached within a few months.

ESA suffers from all the troubles of multi-national, multi-purpose agencies. The latest crisis has been brewing for the past two years as the agency's two largest projects, the Ariane launcher and Spacelab, have been drawing to a close and no new projects of comparable size have been agreed to replace them. Quistgaard's solution, to reduce the agency's total budget from about $£ 480$ million to $£ 285$ million a year by 1982 , has been agreed by most member states. But his suggestions as to how the reduced budget should be spent have opened up old wounds.

West Germany is the only country so far to support Quistgaard's plan to increase the mandatory science budget by 50 per cent over the next decade. Although all are thought to support the notion that the European scientific community should support more space science, few are willing to commit the funds which they would prefer to spend as they wish on voluntary programmes.

The reduced budget will mean that some 